УДК [37.014.53+061.2]:005.8(477) https://doi.org/10.31392/NPU-nc.series12.2019.8(53).08

\title{
ГІДНІСТЬ ЯК ПСИХОЛОГІЧНА СКЛАДОВА МОДЕЛІ СОЦІАЛЬНОГО ПАРТНЕРСТВА
}

\author{
Любов Сокол \\ кандидат психологічних наук, доцент \\ кафедри теоретичної та консультативної психології \\ Національний педагогічний університет імені М. П. Драгоманова \\ 01601, Україна, м. Київ, вул. Пирогова, 9 \\ sokolliubov1975@gmail.com, https://orcid.org/0000-0001-8915-8792
}

\begin{abstract}
Анотація
Соціальне партнерство, як співпраця між учасниками освітнього процесу, громадськими організаціями, приватними й державними установами, є засобом залучення підростаючої молоді до процесів реалізації проєктів широкого спектру. Важливість соціального партнерства висвітлена також у статуті Міжнародної організації праці (ILO), який підкреслює вплив особливостей співпраці між усіма ланками робочого процесу на почуття гідності людини. Соціальний діалог як механізм реалізації партнерства $\epsilon$ фактором впливу на формування та розвиток особистості як члена суспільства. Отже, соціальне партнерство, грунтуючись на безумовному визнанні гідності людини як базової моральної цінності людства, передусім сприяє зміцненню почуття власної гідності на особистісному рівні громадянина. Останній зі свого боку впливає на соціальну поведінку особистості, яка набуває як морального, так і громадянського забарвлення.

На сучасному етапі розвитку української державності потреба у вихованні нової генерації самостійної, критично мислячої, демократичної молоді з розвиненим почуттям гідності стає нагальною. Саме надання переваги цінностям свободи, незалежності та вільній, відповідальній самореалізації закладене у Концепцію нової української школи, яка так само $є$ однією із ланок соціального партнерства у вихованні зростаючого покоління свідомих громадян. Так, визначено, що необхідним психологічним компонентом побудови функціонуючої моделі соціального партнерства є почуття гідності особистості.

В статті представлений аналіз зарубіжного та вітчизняного досвіду побудови моделей соціального партнерства та взаємодії між інституціями різного типу для виховання компетентних, незалежних, креативних, демократичних громадян, проаналізовано психологічний компонент соціального партнерства, а саме гідність особистості. Автором проведене практичне дослідження, спрямоване 3'ясувати смисловий контент, що вкладається у поняття «гідність» студентами психологічних спеціальностей закладів вищої освіти.
\end{abstract}

Ключові слова: соціальне партнерство, моделі соціального партнерства, гідність, виховання громадян, студенти психологічних спеціальностей.

\section{Вступ}

Соціальне середовище на сьогодні апріорі сприймається науковцями як важливий фактор впливу на формування особистості. Значний науковий доробок як вітчизняних, так і зарубіжних науковців підтверджує той факт, що соціальне оточення впливає на думки, 
почуття та поведінку особистості і формує іiі соціальні ролі (Charles, 2019). Основним виховним середовищем підростаючої молоді $є$ школа/однолітки, батьки та громада. Саме завдяки розробці моделей соціального партнерства як складних та ресурсоємних взаємодій міжінституціональних інфраструктур, спрямованих на розвиток потенціалу учнів, можливе підвищення інтелектуальної, моральної, цивілізаційної спроможності нації. Теорія реконструкції, запропонована Ф. Брамелдом, заявляє, що освіта - це найбільш доцільний спосіб відповісти на нове соціальне замовлення суспільства (Danim, 2010). Однак вислів Д. Менделеєва про те, що «освіта без виховання - це меч у руках божевільного», вдало підкреслює необхідність нерозривної єдності між навчальним та виховним процесом. Отже, наш науковий пошук буде спрямований на знаходження оптимальних моделей соціального партнерства, функціонування яких, за нашим припущенням, потребує компетентного керівництва як у процесі створення, так і в управлінні та функціонуванні.

Мета та завдання дослідження: на основі зазначеного метою та завданням став аналіз сучасних моделей соціального партнерства та їхніх компонентів як інструменту виховного впливу на підростаючу особистість.

\section{Методи дослідження}

Для досягнення мети та розв'язання завдань дослідження було використано теоретичні, емпіричні та статистичні методи зведення й обробки даних:

- теоретичні: аналіз нормативно-правового забезпечення діяльності дитячих та молодіжних громадських організацій та об'єднань, спеціальної літератури з досліджуваної проблематики, аналіз, порівняння та узагальнення результатів попередніх досліджень;

- емпіричні: спостереження, анкетування, вивчення й узагальнення педагогічного досвіду, аналіз змісту документів, експертна оцінка.

- статистичні: кількісний і якісний аналіз даних, систематизація та аналітичне групування даних на групи за істотними ознаками, підбиття групових та загальних підсумків.

\section{Результати та дискусії}

Здійснений аналіз дає можливість експлікувати оптимальні моделі соціального партнерства на нинішні форми взаємодії між освітніми закладами різних типів та іншими громадськими, приватними та державними установами.

Попри те, що соціальне партнерство ми розглядаємо як побудову навчальновиховними закладами розгалуженої мережі зв'язків з громадою, урядом та приватними особами чи підприємцями, наголошуємо на тому факті, що метою цього партнерства $є$ підтримка та розвиток підростаючого покоління юних громадян. I саме вони $\epsilon$ тим об'єднувальним центром, навколо і для якого здійснюється партнерська взаємодія, а також виступають єдиним спільним інтересом між інституціями різних форм та рівнів.

Для поліпшення та оптимізації соціальних взаємодій між ключовими учасниками виховного процесу, зокрема сім'єю, освітніми закладами та громадою/державою, розглянемо метод моделювання, запропонований науковцями з університету Negeri Makassar, Indonesia. Посилаючись на роботу С. Даніма (Danim, 2010), дослідники Іслахуддін, I. Толла та Мансюр вважають, що громада повинна відігравати чотири ролі 
для реалізації освітньо-виховної мети, а саме - розширення можливостей, участі, включення та самовизначення (Islahuddin, Tolla \& Mansyur, 2016).

Вчені пропонують створювати матрицю (приклад якої наведений у табл. 1), рядки і стовпчики якої описують функції двох учасників виховного процесу. Так, у табл. 1 нами, 3 використанням методів складання вищезазначеної матриці, зображено взаємодію між освітнім закладом та громадою, за допомогою якої можлива візуальна констатація ліній перетину (збігу) інтересів, функцій зазначених інституцій тощо.

Табличя 1

Синтез партнерства у освітніх установах та громадах/державі

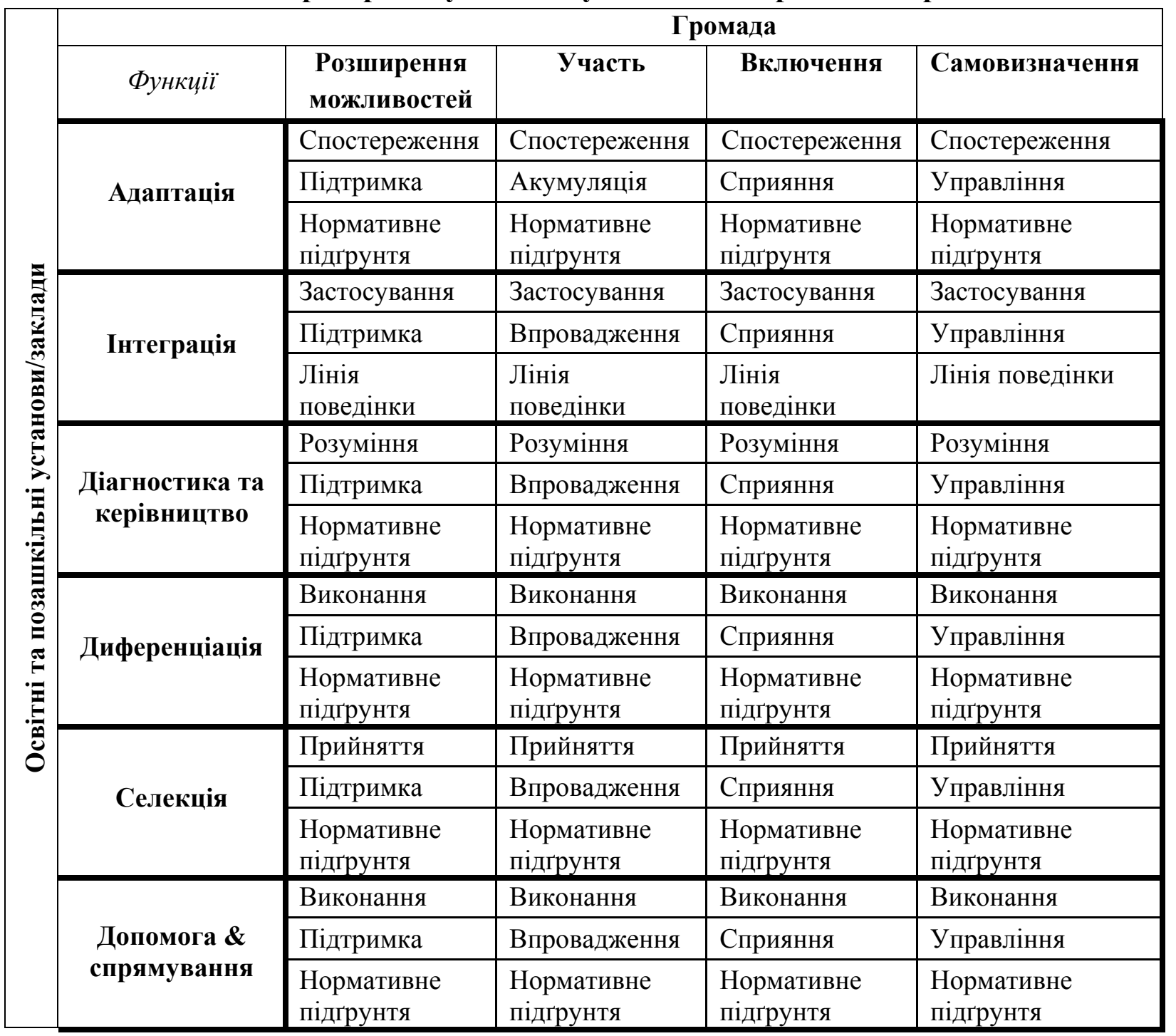

Наведена вище таблиця у вигляді матриці поєднує шість рядків і чотири стовпці, утворюючи 24 квадрата. Пояснимо іiі змістове наповнення. Наприклад, перетин першого рядка та стовпчика охоплює: спостереження, підтримку та лінію поведінки. Спостереження - це такий аспект діяльності освітньої чи позашкільної установи, яка перетинається 3 наглядовими функціями громади. Остання може реалізувати це через комітети з захисту прав дитини, підтримки діяльності дитячих та молодіжних організацій тощо. Другий рядок, підтримка - це очікування освітньої установи від громади. Очікується, що функцію адаптації, яку відіграє освітня установа, повинна підтримувати і 
громада. Наприклад, якщо дітям заборонено здійснювати буллінг/палити/лаятися в освітній установі, то громада може також заважати їм здійснювати таку діяльність, коли вони знаходяться поза закладом освіти чи позашкільною установою. Третій пункт, нормативне забезпечення - це правове ставлення уряду (громади) до взаємних обов'язків та очікувань між ними й закладами шкільної і позашкільної освіти. В нормативному полі такі взаємостосунки можуть реалізуватися через підписання угод, розробку концепцій розвитку тощо.

Хотілося б також висвітлити таку форму партнерства як сприяння. В нашому випадку - це очікування освітніх установ від громади. Очікування полягає у тому, що освітні установи сприяють своїм вихованцям в отриманні основної чи додаткової освіти у межах різноманітних напрямів, які підтримує громада (уряд або місцеве самоврядування). Наприклад, якщо суспільство пропонує дітям можливість займатися музикою, то, в ідеалі, освітні установи повинні мати засоби, необхідні дітям для реалізації цієї потенції (тобто інструменти).

На основі аналізу даних, представлених вище у матриці, зрозуміло, що на сьогодні існують деякі перешкоди в реалізації соціального партнерства між освітніми закладами та громадою (урядом). По-перше, громада сприймає заклади основної та додаткової освіти як такі, від яких можна лише директивно вимагати виконання певних функцій. По-друге, самі освітні заклади не створили інструментів ефективного спілкування з громадою. По-третє, органи шкільного, учнівського самоврядування тощо не виконують свої ролі оптимально, не є центром інформаційної підтримки та розбудови мережі партнерських відносин.

Проаналізувавши значну кількість зарубіжних наукових робіт з проблематики соціального партнерства i спираючись на напрацювання вчених Індонезійського університету, ми мали можливість експлікувати їхній досвід на наші українські реалії й представити модель соціального партнерства у вигляді рисунку 1.

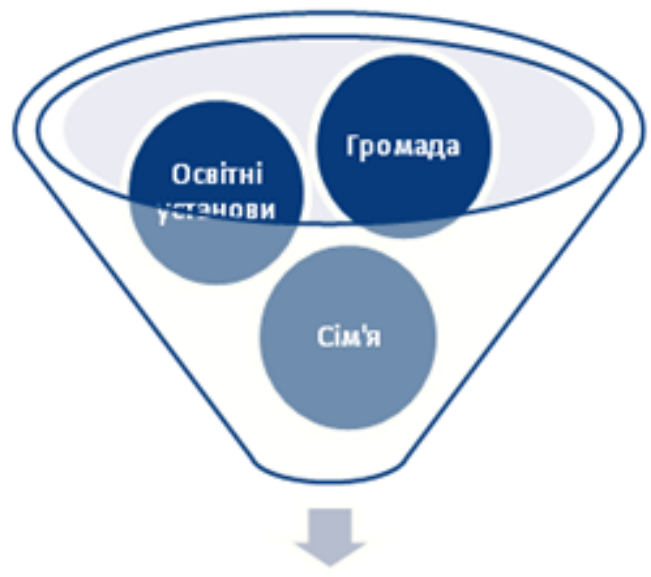

Вихованці

\section{Рис.1. Модель соціального партнерства «сім'я-громада-освітні заклади»}

Центром моделі є вихованець - спільна точка дотику між трьома інституціями: сім'єю (приватними особами), громадою та освітніми закладами. Вихованець, в нашому випадку, сприймається нами інтегрально, як особистість, яка поєднує в собі всі соціальні ролі - і учня, і громадянина, і дитини (підлітка), і члена громади (суспільства) тощо. I основні джерела виховного впливу діють комплексно, на всю структуру особистості, апелюючи до його знань, почуттів та досвіду. 
Бажаний рівень соціального партнерства - це тотальне партнерство, який неможливо досягти без спільних цілей, які грунтуються на особистісній потребі кожного учасника в їх реалізації.

Саме на останній психологічний компонент ми хотіли б звернути більш пильну увагу. Базовим психологічним компонентом особистості, яка воліє до створення проєкту соціального партнерства 3 іншими, є почуття гідності. На взаємозв'язок власної гідності 3 гуманізмом, свободою, справедливістю, рівністю, вказували сучасні дослідники-педагоги, підкреслюючи той факт, що саме в ній закладені базові цінності соціуму, загальнолюдські гуманістичні засади, які і визначають підгрунтя та вектор взаємодії між учасниками соціального партнерства.

На думку науковців П. Лі та Р. Джорджа, гідність - це той раціональний компонент самосвідомості особистості, який має лише людина. Автори наполягають на тому, що всі люди мають справжню гідність просто тому, що вони від народження $є$ істотами 3 природними здатностями до свободи думки та вільного вибору, формування власного життя. Через грунтовні наукові розмірковування автори приходять до висновку, що базова гідність тотожна з поняттям просто бути людиною (Lee \& George, 2008).

Інший автор у статті «Віра в гідність людських ембріонів» («Believing in the Dignity of Human Embryos»), наполягає на тому, що почуття гідності наявне вже у людського ембріону (Hauskeller, 2011). Достатнім обгрунтуванням для такого висновку, є наявність тих самих прагматичних підстав, які в кінцевому підсумку приводять особистість до поваги інших людей як носіїв гідності як особливої моральної цінності.

Більше того, зважаючи на той факт, що без урахування почуття гідності особистості неможлива побудова ефективної комунікації, автори деяких статей 3 робототехніки пропонують власні розробки у сфері надання носіям штучного інтелекту можливості ставитися до них як до особистостей, тобто прагнуть надати морального статусу небіологічним істотам з повним урахуванням їхніх уявних інтересів, прав, обов’язків та можливостей для етично значущої діяльності (Bess, 2018).

Р. МакКлелленд у статті «Натуралістичний погляд на гідність людини» («А Naturalistic View of Human Dignity») пропонує три основні біологічні контексти для розуміння гідності в натуралістичному аспекті: взаємодії та покарання (оскільки обидва залучаються до пропагування просоціальної кооперативної поведінки між людьми) та гідності як комунікативного сигналу, який також має силу сприяти співпраці (McClelland, 2011). Кожен із цих трьох компонентів досліджується докладно, з опорою на широкий спектр сучасної наукової літератури. Крім того, автор пропонує методи вивчення гідності повністю науковим шляхом, адаптуючи методи, прийоми, які вже існують в біологічному, фізіологічному та нейронауковому вимірах людської співпраці. Серед таких методів Р. МакКлелленд називає проєктивні методики дослідження поведінки особистості, зокрема «Міжнародну систему афективних зображень» («The International Affective Picture System»), що широко використовується для вивчення афективних відповідей на стандартні мімічні зображення обличчя людини, а також методики тестування афективних корелятів (Gobl \& Chasaide, 2000), що визначають реакцію на так звану «якість голосу», а саме: «впевнений», «доброзичливий», «зацікавлений», «нейтральний» тощо. Дослідники роблять висновок про релевантність афективних виразів всього тіла, мімічних та голосових проявів емоцій компонентам гідності (Allan \& Davidson, 2013; McClelland, 2011). 
Зазначений вище натуралістичний підхід сучасних зарубіжних психологів докорінно відрізняється від звичної нам «приналежності» феномена гідності до сфери виховання та моралі. Дилема визначення витоків гідності актуалізувала в нас бажання практично дослідити уявлення студентів-психологів щодо цього феномена. 3 цією метою ми розробили опитувальник, який складався 3 п'яти запитань, останнє 3 яких мало ілюстративний характер і було покликане визначити ситуації, в яких досліджувані фіксували прояв гідності у поведінці оточуючих. Загальна вибірка опитаних респондентів становила 96 осіб. Всі опитувані були студентами психологічного факультету старших курсів, що давало нам змогу припустити, що вони орієнтуються в змісті психологічних дисциплін і дадуть більш психологічно обгрунтовані відповіді, ніж їхні однолітки з інших факультетів.

Перше питання полягало у визначенні суті поняття «гідність». Думки студентів можна умовно поділити на декілька груп, а саме.

Гідність - як показник розвитку самосвідомості (самосприйняття, самооцінка та самоставлення). Для цієї групи характерними були визначення на зразок: це те, «що присутнє в людині, яка себе цінує та поважає»; «усвідомлює свою важливість щодо себе»; «самоповага та підтримання певного рівня поваги у власних очах»; «прояв самоповаги»; «почуття своєї важливості, совісності, почуття того, що ти чогось вартий»; «це шанобливе ставлення до себе з моральної точки зору, підпорядковуючись моральним якостям та етиці». (Примітка автора - тут та далі в лапках наводяться изитати з анкет респондентів).

Гідність - як суспільно-особистісне поняття. До цієї групи потрапили висловлювання на зразок: «гідність - це відносне почуття усвідомлення та відчуття свого «Я» щодо суспільства, пов'язане з почуттям справедливості»;

Гідність - як установка чи поведінкова модель. Анкети цієї групи визначались такими характеристиками, як: «певна психологічна установка в житті, в основі якої лежать суспільно-визначені норми», «...це схильність особистості усвідомлювати свої принципи, права, обов'язки. Не піддаватись психологічному впливу інших»; «це моральні цінності людини, iї поведінка»

Гідність - як суспільна оцінка людини. Досліджувані цієї групи давали визначення гідності як «поняття моральної свідомості, яке виражає уявлення про цінність будь-якої людини як моральної особистості»;

Загалом можна назвати дві загальні тенденції у тлумаченні студентами поняття гідності, а саме: розуміння гідності через самоусвідомлення та визнання іiі наслідком порівняння власних досягнень з очікуваннями суспільства. Водночас кількісний розподіл «прихильників» однієї та іншої детермінації розподілилися так: 69,8\% респондентів воліють зараховувати гідність до сфери самосвідомості особистості, а 30,2\% - до сфери моральних оцінок з боку суспільства (рис. 2). Такий розподіл відповідей не зовсім співвідноситься з відповідями на питання про природу гідності (набуту чи природжену). 97\% опитаних вважають, що почуття гідності виникає внаслідок виховання або моральних вимог соціуму, і лише 3\% - вбачають природжений характер цього почуття, яке, проте, розвивається та коригується внаслідок життєдіяльності. Зазначена неузгодженість пояснюється, на наш погляд, слабкою обізнаністю студентів зі сферою моральної саморегуляції особистості, що вносить плутанину у процес їх розмірковувань. 


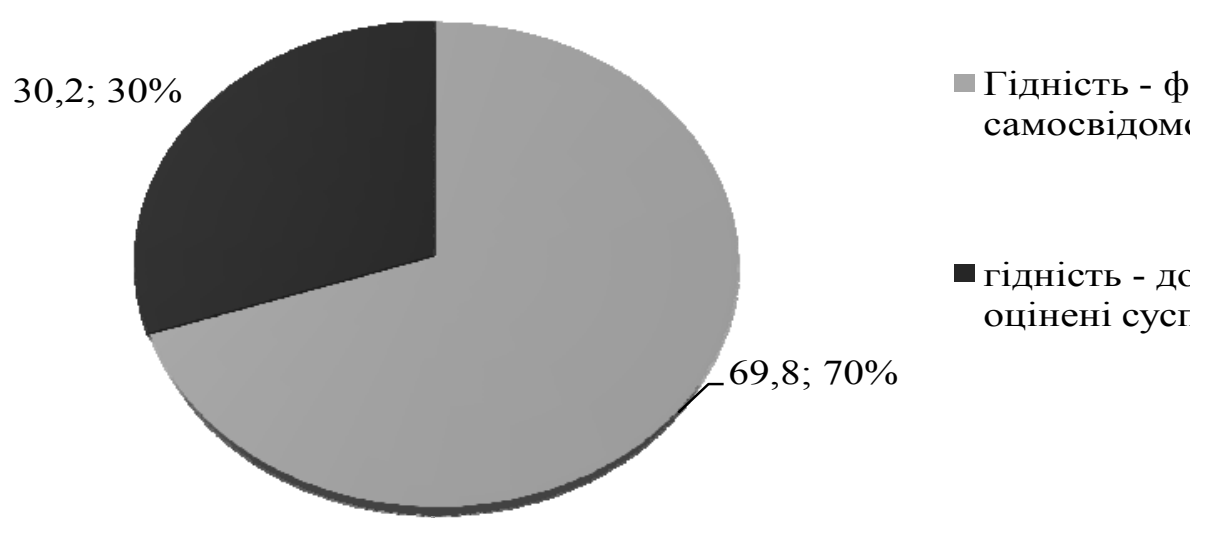

Рис. 2. Трактування поняття гідності

Цікавими були відповіді опитуваних на питання, що стосувалося прикладів ситуацій прояву гідності особистості. Тут нами помічено декілька тенденцій (рис. 3).

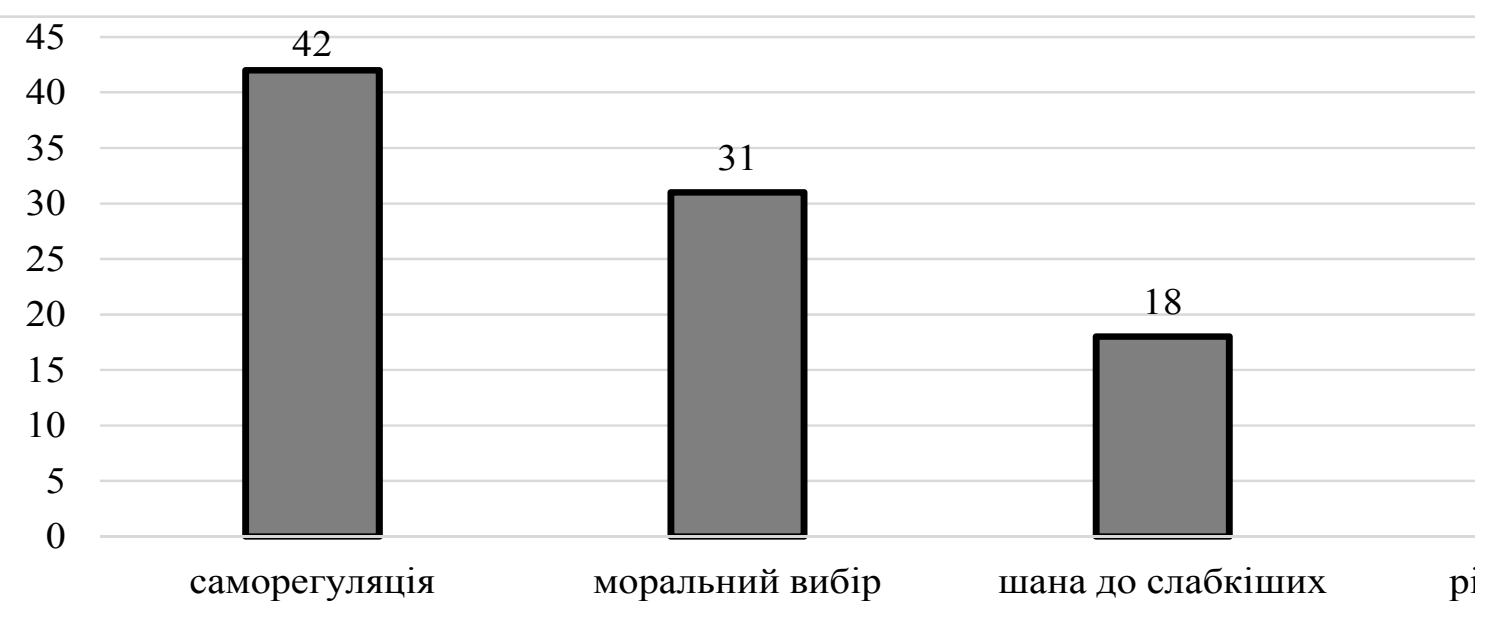

Рис. 3. Розподіл відповідей-пояснень ситуацій прояву гідності (\%)

Існувала найчисленніша група студентів (42\%), що вбачали прояви гідності у ситуації емоційної саморегуляції («не зриватися на крик», «істерію», вести себе раціонально та виважено тощо). Інша група (31\%) апелювала до ситуацій морального вибору - врятувати чиєсь життя, загасити пожежу; «захищати благородно свою країну», відстоювання прав особистості на повагу, самопожертва тощо. Третя група пов'язувала ситуації прояву гідності з шанобливим ставленням до немічних, хворих, дітей та інших (18\%). Ще одна група опитуваних трактувала як гідну поведінку ситуацію, що визначала високий рівень домагань людини щодо місця в суспільстві (9\%). Таку неодностайність у прикладах прояву гідності ми пов'язуємо 3 широким спектром ситуацій морального характеру, що реалізують у собі потенціал гідної поведінки, і з недостатнім досвідом їх аналізу у майбутніх фахівців.

Нас також цікавило розуміння студентами різниці між поняттями «честь» та «гідність». Ми виявили значні розбіжності між трактуваннями цих феноменів та відсутність узгодженості між ними. Так, деякі з респондентів вважали, що вказані для тлумачення категорії - це «сторони однієї медалі», другі вказували на те, що честь, на відміну від гідності, можна втратити, треті - що честь - це винагорода за гідність та ії 
похідна, четверті - честь - ситуативна і залежить від обставин, п’яті - честь - це прояв особистості у соціальному вимірі, а гідність - різновид самоставлення. Така різноспрямованість поглядів з заданого питання вказує на значні труднощі учасників опитування, пов'язані 3 узагальненням досвіду використання складних моральних імперативів у практичній діяльності і недостатність професійної підготовки в цій сфері. Останнє зі свого боку негативно впливає на процес особистісного зростання молоді через несформованість однозначного вектору їх морального розвитку, що проявляється в їхніх більш інтуїтивних, аніж критично осмислених висновках щодо важливих чинників соціальної життєдіяльності людини.

Водночас необхідно зазначити, що переважна більшість респондентів (98\%) звернула увагу на взаємозв'язок між гідністю особистості та її залученістю до програм із соціального партнерства, вказавши на той факт, що останнє вимагає від учасників взаємодії взаємоповаги та гідного ставлення один до одного. Саме 3 врахуванням цих компонентів можливе тотальне партнерство - взаємодія за повним типом співпраці, характеристиками якої $\epsilon$ : складання угод, спільне бачення процесу, досягнення консенсусу та співпраця.

Як видно 3 аналізу джерел, соціальне партнерство реалізується найкраще за наявності соціально значущої спільної мети, що продиктована високими цінностями буття, головною з яких є гідність особистості.

\section{Висновки}

Хоча гідність у класичній філософії поєднується з поняттям самотності й іноді, навіть, протиставлення себе суспільству, ми можемо казати, що, з психологічної точки зору, гідна людина - це та людина, яка здатна робити свідомий вибір на самореалізацію і організовувати навколо себе людей, об'єднаних моральними цінностями людства. Особистість 3 розвиненим почуттям гідності стає морально активною та небайдужою до подій, що відбуваються навколо неї. Вона проявляє громадянську активність та позицію, надаючи пріоритет моральним цінностям, залучається до соціального партнерства 3 іншими особами та організаціями, що мають за мету обстоювання цінностей свободи та демократії. Перспективи подальших досліджень вбачаємо у детальному вивченні психологічного феномена гідності як фактору впливу на прийняття особистістю рішень 3 метою з'ясування природи і механізмів його функціонування.

\section{Література}

1. Бех, І.Д. (2009). Почуття гідності у духовному розвитку особистості. Психологічні джерела виховної майстерності. Київ : Академвидав.

2. Дойчик, М.В. (2018). Ідея гідності в історії європейської філософії. (Монографія). Івано-Франківськ : Прикарпат. нац.ун-т ім. В.Стефаника.

3. Allan, A., \& Davidson, G.R. (2013). Respect for the Dignity of People. Australian Psychologist, 48(5), 345-352. https://doi.org/10.1111/ap.12012

4. Bess, M. (2018). Eight Kinds of Critters: A Moral Taxonomy for the Twenty-Second Century. The Journal of Medicine and Philosophy: A Forum for Bioethics and Philosophy of Medicine, 43(5), 585-612. https://doi.org/10.1093/jmp/jhy018

5. Gobl, Ch., \& Chasaide, A.N. (2000) Testing affective correlates of voice quality through analysis and resynthesis. Proceedings from SaE' 00: ITRW on Speech and Emotion 
(Newcastle, Northern Ireland, UK, September 5-7, 2000) (pp.178-183). Retrieved from https://www.isca-speech.org/archive open/archive_papers/speech_emotion/spem_178.pdf

6. Islahuddin, Tolla, I. \& Mansyur (2016). A Holistic Model of Partnership in Education. International Journal of Environmental and Science Education, 11(13), 5915-5924. Retrieved from http://www.ijese.net/makale indir/752

7. Danim, S. (2010). Introduction to Education, the Theoretical Basis, and Educational Metaphor. Bandung: Alfabeta.

8. Hauskeller, M. (2011). Believing in the Dignity of Human Embryos. Human Reproduction \& Genetic Ethics, 17 (1), 53-65. https://doi.org/10.1558/hrge.v17i1.53

9. Herrman, Ch. (2019). What Is Dignity? Eidos. A Journal for Philosophy of Culture, 3(3), 103-126. https://doi.org/10.14394/eidos.jpc.2019.0033

10. Lee, P. \& George, R. (2008). The Nature and Basis of Human Dignity. Ratio Juris, 21, 173 93. https://doi.org/10.1111/j.1467-9337.2008.00386.x

11. McClelland, R.T. (2011). A Naturalistic View of Human Dignity. The Journal of Mind and Behavior, 32(1), 5-48. Retrieved from www.jstor.org/stable/43854287

\section{References}

1. Bekh, I.D. (2009). Pochuttia hidnosti u dukhovnomu rozvytku osobystosti. Psykholohichni dzherela vykhovnoi maisternosti [Feeling of dignity in the spiritual development of the individual. Psychological sources of educational masters]. Kyiv : Akademvydav [in Ukrainian].

2. Doichyk, M.V. (2018). Ideia hidnosti v istorii yevropeiskoi filosofii [The idea of dignity in the history of European philosophy]. Ivano-Frankivsk : Prykarpat. nats. un-t im. V.Stefanyka [in Ukrainian].

3. Allan, A., \& Davidson, G.R. (2013). Respect for the Dignity of People. Australian Psychologist, 48(5), 345-352. https://doi.org/10.1111/ap.12012

4. Bess, M. (2018). Eight Kinds of Critters: A Moral Taxonomy for the Twenty-Second Century. The Journal of Medicine and Philosophy: A Forum for Bioethics and Philosophy of Medicine, 43(5), 585-612. https://doi.org/10.1093/jmp/jhy018

5. Gobl, Ch., \& Chasaide, A.N. (2000) Testing affective correlates of voice quality through analysis and resynthesis. Proceedings from SaE' 00: ITRW on Speech and Emotion (Newcastle, Northern Ireland, UK, September 5-7, 2000) (pp.178-183). Retrieved from https://www.isca-speech.org/archive open/archive_papers/speech_emotion/spem_178.pdf

6. Islahuddin, Tolla, I. \& Mansyur (2016). A Holistic Model of Partnership in Education. International Journal of Environmental and Science Education, 11(13), 5915-5924. http://www.ijese.net/makale indir/752

7. Danim, S. (2010). Introduction to Education, the Theoretical Basis, and Educational Metaphor. Bandung: Alfabeta

8. Hauskeller, M. (2011). Believing in the Dignity of Human Embryos. Human Reproduction \& Genetic Ethics, 17(1), 53-65. https://doi.org/10.1558/hrge.v17i1.53

9. Herrman, Ch. (2019). What Is Dignity? Eidos. A Journal for Philosophy of Culture, 3(3), $103-$ 126. https://doi.org/10.14394/eidos.jpc.2019.0033

10. Lee, P., \& George, R. (2008). The Nature and Basis of Human Dignity. Ratio Juris, 21, $173-$ 93. https://doi.org/10.1111/j.1467-9337.2008.00386.x

11. McClelland, R.T. (2011). A Naturalistic View of Human Dignity. The Journal of Mind and Behavior, 32(1), 5-48. Retrieved from www.jstor.org/stable/43854287 


\title{
DIGNITY AS A PSYCHOLOGICAL COMPONENT OF THE SOCIAL PARTNERSHIP MODEL Liubov Sokol \\ PhD in Psychology, Associate Professor \\ of the Department of Theoretical and Counselling Psychology \\ National Pedagogical Dragomanov University \\ 9, Pyrohov Str., Kyiv, Ukraine, 01601 \\ sokolliubov1975@,gmail.com, https://orcid.org/0000-0001-8915-8792
}

\begin{abstract}
Social partnership, as a collaboration between participants in the educational process, public organizations, private and public institutions, is a means of involving young people in the processes of implementation of broad spectrum projects. The importance of social partnership is also reflected in the statute of the International Labor Organization (ILO), which emphasizes the impact of cooperation between all parts of the work process on the human dignity. Social dialogue as a mechanism for the realization of partnership is a factor influencing the formation and development of the individual as a member of society. Thus, social partnership, based on the unconditional recognition of human dignity as the basic moral value of humanity, above all contributes to the strengthening of self-esteem at the personal level of the citizen. The latter, in turn, affects the social behavior of the individual, which acquires both moral and civic color.

At the current stage of the development of Ukrainian statehood, the need to educate a new generation of independent, critically minded, democratic youth with a developed sense of dignity becomes an urgent need. It is precisely the preference for the values of freedom, independence and free, responsible self-realization that is embedded in the concept of a new Ukrainian school, which also serves as one of the links of social partnership in the education of a growing generation of conscious citizens. Thus, it is determined that a necessary psychological component of building a functioning model of social partnership is the sense of dignity of the individual.

The article presents the analysis of foreign and domestic experience of building interaction models of institutions of different types for education of competent, independent, creative, democratic citizens, analyzes the psychological component of social partnership, namely the dignity of the individual. The author conducted a practical study aimed to find out the meaningful content that fits into the concept of «dignity» of students of psychological specialties of higher education.
\end{abstract}

Keywords: social partnership, models of social partnership, dignity, education of citizens, students of psychological specialties.

Подано 16.12.2019

Рекомендовано до друку 24.12.2019 